Ks. Franciszek DRĄCZKOWSKI (Lublin, KUL)

\title{
OBOWIĄZKI I PRZYWILEJE LUDZI STARSZYCH WEDLUG KLEMENSA ALEKSANDRYJSKIEGO
}

1. Uprzywilejowanie wieku sędziwego. Na wstępie należy nadmienić, że Klemens Aleksandryjski, generalnie rzecz biorąc, reprezentuje optymistyczną wizję wieku sędziwego. Daje się to zauważyć na kartach wszystkich jego pism, gdzie wręcz promuje wiek starczy jako, z wielu względów uprzywilejowany. Co więcej, sądzi, że postępujący wiek ludzi starszych, jest tytułem do zyskiwania coraz większego szacunku i czci ze strony młodszych. Do tych wszystkich, którzy nie podzielali jego optymizmu zwraca się w słowach:

„Czemu ma się człowiek wstydzić starości? Wszak im bardziej zbliża się do końca życia, tym jest czcigodniejszy, bo wiekiem przewyższa go chyba tylko sam Bóg, ów odwieczny starzec, starszy od całego świata"'.

Już samo zestawienie, w powyższej wypowiedzi, człowieka starego z oso-

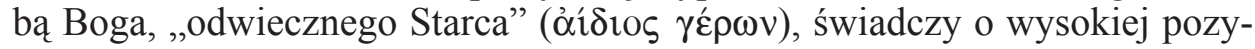
cji, jaką Klemens wyznacza ludziom sędziwym. Można nawet dopatrzyć się, w powyższej wypowiedzi, formy ukrytej apoteozy wieku starczego. Człowiek sędziwy, „im bardziej zbliża się do końca życia, tym jest czcigodniejszy”. Starzec ma tylko Boga starszego od siebie.

Tytułem tej wysokiej rangi i nobilitacji wieku starczego, jest mądrość i doświadczenie, które starzec zdobywa i gromadzi w ciągu swego całego długiego życia. Odwołując się do autorytetu biblijnego, Klemens stwierdza:

„Czytamy w Piśmie Świętym: «Koroną starości bogactwo doświadczenia»

(Syr 25, 6); tego właśnie doświadczenia oznaką bywa siwizna”3.

Należy dodać, że Klemens do tego stopnia starość wiąże z posiadaniem mądrości, że w wielu jego wypowiedziach termin „starość” jawi się jako synonim mądrości i wiedzy. Daje się to szczególnie zauważyć w dyskusji z Hellenami,

${ }^{1}$ Clemens Alexandrinus, Paedagogus III 16, 4, ed. O. Stählin, GCS 12, 246, tłum. M. Michalski, w: tenże, Antologia literatury patrystycznej (= ALP), I, Warszawa 1975, 351. Dalsze teksty z Pedagoga cytuję w przekładzie M. Michalskiego, zawartym w tej Antologii.

${ }^{2}$ Tamże.

${ }^{3}$ Paedagogus III 17, 1, GCS 12, 246, ALP I 351. 
którym zarzuca, że nie posiadają „żadnej wiedzy okrytej siwizną wieków”4. Przypomina, że Platon przez „starców” rozumiał „ludzi znających stare dzieje, to znaczy nasze”5. „Starcy”, zdaniem Klemensa, winni też legitymować się wysoką formacją moralną. Z jego wypowiedzi wynika, że zdawał on sobie $\mathrm{z}$ tego sprawę, że nie wszyscy dosięgali tego ideału ${ }^{6}$.

Warto też zauważyć, że z drugiej strony Klemens nie idealizuje wieku sędziwego, wręcz przeciwnie, świadom jest przywar i ułomności z nim związanych. Poważną przywarą wieku starczego jest zapominanie. Klemens wyznaje, że sam doświadcza tej ułomności. Przystępując do redakcji swego dzieła Stromateis, pisze:

„A wiem dobrze, iż wiele rzeczy ulotniło się z naszej pamięci dlatego, że przez długi czas pozostawały nie zapisane. [...] Pewne myśli w ogóle nie zostały utrwalone w mojej pamięci, $[\ldots]$ pewne znowu, jako nie zanotowane, tylko przez pewien czas trzymały się pamięci, ostatecznie w chwili obecnej z niej wypadły"7.

Człowiek w wieku bardzo sędziwym, często staje się do tego stopnia zniedołężniałym, że wymaga takiej opieki, jaką świadczy się dziecku. Mając to na uwadze, Klemens cytuje opinie starożytnych autorów, potwierdzające ten pogląd:

„Teopomp taki ułożył wiersz:

«Powtórnie dziećmi starcy są, to słuszny sąd».

Przed nim już Sofokles w Peleusie tak powiedział:

«Peleusa Ajakidę pod opieką mam

W starości jego i jak dziecko wiodę znów.

Bo dzieckiem jest powtórnie w starszym wieku mąż».

A retor Antyfont mówi: «Pielęgnacja starców przypomina pielęgnację dzieci». Filozof Platon podobnie: «... więc starzec może stać się, jak się okazuje na nowo dzieckiem»"s.

Powyższe opinie Klemens co prawda cytuje, lecz, w istocie rzeczy, nie podpisuje się pod nimi. W jego dziełach dominuje zdecydowanie obraz pogodnej i szczęśliwej starości. Ludzie sędziwi zajmują naczelne miejsca w życiu kulturowym, religijnym i towarzyskim; można wręcz powiedzieć, że stoją na samym szczycie drabiny społecznej. Status ten wiąże się zarówno z wieloma

${ }^{4}$ Clemens Alexandrinus, Stromata I 180, 3, ed. O. Stählin - L. Früchtel, GCS 52, 110, thum. J. Niemirska-Pliszczyńska: Klemens Aleksandryjski, Kobierce, I, Warszawa 1994, 123. Dalsze teksty ze Stromatów cytuję również w przekładzie J. Niemirskiej-Pliszczyńskiej; por. Clemens Alexandrinus, Protrepticus 108, 2-3; Stromata I 69, 3.

${ }^{5}$ Por. Stromata I 180, 2, GCS 52, 110, thum. Niemirska-Pliszczyńska I 123; zob. Plato, Timaios 22B.

${ }^{6}$ Por. tamże.

${ }^{7}$ Tamże I 14, 2-3, GCS 52, 10, tłum. Niemirska-Pliszczyńska I 10-11.

${ }^{8}$ Tamże VI 19, 5-8, GCS 52, 438, thum. Niemirska-Pliszczyńska II 120; por. Teopompus, Frg. 69 , CAF I, s. 751; Sophocles, Peleus, Frg. 447, TGF, s. 239; Antiphon, Frg. 136 Blass; Plato, Leges I 646A. 
przywilejami, jak i obowiązkami. Najbardziej daje się to zauważyć w życiu codziennym, którego wzorcowy model przedstawia Klemens w swym dziele Pedagog. Mając na uwadze skromne ramy niniejszego opracowania, pragniemy głównie skupić się na zasadach savoir-vivre, wyłożonych przez Klemensa, w wyżej wspomnianym dziele. Na płaszczyźnie życia towarzyskiego, bywa zazwyczaj tak, że przywileje i obowiązki są ze sobą ściśle powiązane; najczęściej przywileje pociaggają za sobą określone obowiązki i na odwrót, obowiązki wiążą się z określonymi przywilejami. $Z$ tej racji, również w niniejszej pracy będziemy o nich referować łącznie.

\section{Uprzywilejowanie starców w zakresie konsumpcji wina, podczas} spotkań towarzyskich. Warto przypomnieć, że kwestii spożywania napojów Klemens poświęca cały rozdział drugi, II księgi Pedagoga, pt. Jak należy uży-

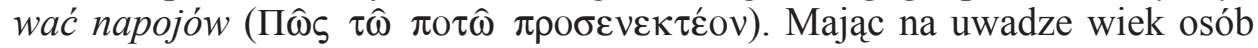
uczestniczących w ucztach, Klemens stawia dość rygorystyczne trzy zasady, dotyczące picia wina przez ludzi w różnym wieku. W myśl tych reguł, starcy moga pozwolić sobie podczas uczt na dość swobodną konsumpcję wina; ludzie w wieku średnim winni starannie ograniczać ilość spożywanego trunku, zaś młodzież powinna zachowywać całkowitą abstynencję od spożywania wina. Ten ostatni zakaz, dotyczący ludzi młodych, Klemens uzasadnia względami obyczajowymi, następująco:

„Przede wszystkim chłopcy i dziewczęta powinni jak najdłużej wstrzymywać się od wina. Nie można przecież w młody organizm wlewać najgorętszego ze wszystkich płynów; byłoby to dorzucaniem ognia do ognia. Wszak od niego zapalają się wszystkie gwałtowne namiętności, gorące żądze, ogniste obyczaje; młodzież rozgrzana od wewnątrz staje się łatwiej podatna na poruszenia zmysłowe, co zaraz odbija się szkodliwie już na samym jej ciele, powodując przedwczesne dojrzewanie organów płciowych. Podniecane winem nabrzmiewają piersi i części wstydliwe, a w wyobraźni zarysowuje się obraz ewentualnego cudzołóstwa. Od ciała zaś zaogniają się rany duszy, wzmagają nieczyste pragnienia, prowokując nawet spokojnego skądinąd człowieka do czynów niegodziwych; ostatecznie kończy się na tym, że burzliwa krew młodzieńcza przerywa wszelkie tamy wstydliwości. Jak najusilniej więc trzeba się starać gasić ogień młodzieńczych popędów, odsuwając z jednej strony płonącą żagiew bakchusowego napoju, a z drugiej stosując środki, które by chłodziły rozpaloną duszę, kurczyły nabrzmiewające członki, uśmierzały budzącą się pożądliwość"”.

Podobnie Klemens uzasadnia „tolerancyjną” zasadę picia wina przez starców, mając na uwadze względy zdrowotne, jak i obyczajowe:

„Dopiero ludziom starym wolno nieco swobodniej używać trunku, jako że muszą oni swój wyziębły już i wiekiem osłabiony organizm podniecać lekar-

\footnotetext{
${ }^{9}$ Paedagogus II 20, 3 - 21, 1, GCS 12, 168, ALP I 345-346.
} 
stwem winnego grona. Nie przynosi im to zresztą zazwyczaj większej szkody, bowiem w tym okresie życia pożądliwości nie bywają już tak silne, by podchmielenie sobie groziło od razu katastrofą. Zarówno rozum, jak wiek same trzymają starców na uwięzi, niby kotwice okręt w porcie i ułatwiają im opieranie się burzom namiętności, wzniecanym przez nadmiar napitku. Toteż nikt nie bierze im za złe, gdy sobie nawet podczas uczty pozwalają na żarty i dowcipy, oczywiście byle tylko zachowywali przy piciu odpowiednie granice, to jest utrzymywali niezamroczony umysł, pamięć oraz panowanie nad ruchami ciała [...]. W każdym razie powinni raczej wcześniej przerwać picie, by nie narazić się na niebezpieczeństwo upadku. O ile sobie przypominam, niejaki Artoriusz twierdzi w swym dziele $O$ dlugim życiu, że kto chce dożyć późnej starości, powinien pić tylko tyle, ile potrzeba do zwilżenia potraw"10.

Jak wynika z powyższej wypowiedzi, przywilej „swobodnego używania trunku”, przynależny starcom, wiąże się z określonymi obowiązkami, które wynikają z zasady zachowania umiaru. Starzec winien przestrzegać „odpowiednich granic” w piciu wina. Winien spożyć tylko taką ilość „bakchusowego napoju”, która pozwoli mu zachować „niezmącony umysł” oraz należytą pamięć. Jego obowiązkiem jest też zachować taką miarę picia wina, która by nie zakłóciła jego ,panowania nad ruchami ciała”. Z tej racji Klemens konkluduje, że obowiązkiem starca jest „raczej wcześniej przerwać picie” wina.

Należy dodać, że wyżej podane zasady, dotyczące umiarkowanego picia wina, nie stanowią ideału Klemensowej ascezy. Nasz autor w pełni aprobuje zasadę całkowitej wstrzemięźliwości od używania wina, o czym świadczy jego następująca wypowiedź:

„Pochwalam i podziwiam tych, którzy surowe obrali życie i poprzestają na wodzie, lekarstwie wstrzemięźliwych, przed winem zaś uciekają jak najdalej, niby przed groźbą pożaru"11.

\section{Przywilej przewodzenia rozmowom towarzyskim w czasie uczt.} Reguły dotyczące prowadzenia rozmów w czasie uczt, to jest ,„przyjęć proszo-

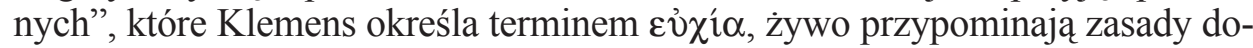
tyczące spożywania wina. Starcy podczas uczt są uprawnieni do częstego zabierania głosu; młodzież i kobiety - winny zachować daleko idącą powściągliwość w mowie, skłaniając się raczej do słuchania i milczenia. Klemens, powołując się na autorytet biblijny, swoje stanowisko w tej kwestii, przedstawia następująco:

„Milczenie jest cnotą niewiast, a zawsze pożyteczną zaletą młodzieńców; ludziom starszym natomiast przystoi rozmowność. «Mów starcze podczas

${ }^{10}$ Tamże II 22, 3 - 23, 1, GCS 12, 169-170, ALP I 346. Aratoriusz Asklepiades - lekarz z czasów Augusta, por. RE M. Wellmann, M. Aratorius Asclepiades 4, RE II/2 1461.

${ }^{11}$ Tamże II 20, 2, GCS 12, 168, ALP I 345. 
uczty, ale mów płynnie i tylko o tym, co wiesz; ty zaś młodzieńcze [...] mów, jeśli jest konieczne, ale dopiero wtedy, gdy cię dwukrotnie zapytają, oraz tylko krótko i zwięźle» (Syr 32, 4, 10)"12.

Ta uprzywilejowana rola starców, jest - jak wynika z powyższej wypowiedzi - obwarowana określonymi obowiązkami. Starzec powinien mówić „płynnie”

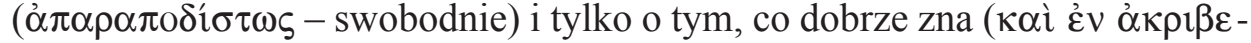

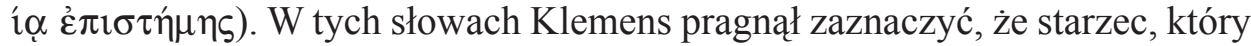
ma pierwszeństwo głosu w towarzystwie, winien unikać „rozwlekłego zrzędzenia", ględzenia i bezsensownego gadulstwa ( $\varphi \lambda v \alpha \rho i ́ \alpha)$. Jego mowa winna być dorzeczna i logiczna; płynna i zrozumiała.

Należy zaznaczyć, że Klemens bardzo wiele uwagi poświęca sprawie należytego prowadzenia konwersacji. Ponieważ starcy mają przewodzić rozmowom, do nich w pierwszym rzędzie należy odnieść następujące zasady, podane przez Klemensa:

„Jeśli zaś dwóch ludzi rozmawia z sobą, niechże każdy z nich zachowuje odpowiednią siłę głosu. Krzyczenie przy rozmowie jest największą głupota, ale nierozumne jest również, gdy ktoś mówi za cicho, tak, że nawet najbliżsi sąsiedzi nie mogą zrozumieć, o co mu chodzi, i przestają go wreszcie słuchać. Unikać też należy w rozmowie wszelkiej gwałtownej szermierki słownej, byle za wszelką cenią odnieść nad przeciwnikiem zwycięstwo: wszak naszym ideałem jest spokój ducha. Dlatego przecież mówimy: «Pokój z tobą». «Nie mów ani słowa, zanim nie wysłuchałeś drugiego» (Syr 11,8), ale znów zbyt słaby, załamujący się głos dowodzi zniewieściałości mówiącego. Człowiek stateczny i roztropny zachowuje umiarkowaną siłę głosu, unika pokrzykiwania i rozwlekłego gadulstwa, nie mówi zbyt szybko ani też nie zalewa słuchaczy potokiem słów [...]. «Straszny jest w zepsuciu swym człowiek gaduła» (Syr 9, 25), bo i rzeczywiście przypomina on stare buty, w których wszystko już się zdarło z wyjątkiem samego języka, zachowanego na utrapienie drugich. Toteż nader życiową radę daje Mądrość: «Nie bądź gadatliwy, gdy znajdziesz się w gronie starców» (Syr 7, 15). Aby zaś z gruntu wyplenić gadulstwo podkreśla, że należy zachować umiar poczynając już od przemawiania do samego Boga: «Nie powtarzaj - powiada po dwakroć ani jednego słowa w czasie modlitwy» (tamże)"13.

$\mathrm{Na}$ marginesie powyższej wypowiedzi, nasuwa się refleksja, że powyższe zasady nic nie straciły na swej aktualności. Jakże często bierzemy udział w spotkaniach, gdzie mówca zabierający głos mówi zbyt szybko, ,zalewając słuchaczy potokiem słów" i tak cicho, że nawet najbliżsi sąsiedzi nie mogą zrozumieć, o co mu chodzi, ,i przestają go wreszcie słuchać”.

Warto też dodać, że Klemens Aleksandryjski, wytrawny pedagog i nauczyciel, nie pomija okazji, by promować oddziaływanie wychowawcze, mając na

\footnotetext{
${ }^{12}$ Tamże II 58, 1-2, GCS 12, 192, ALP I 349.

${ }^{13}$ Tamże II 58, 3 - 59, 4, GCS 12, 192-193, ALP I 350.
} 
celu dobro młodego pokolenia. Jego zdaniem starzec „wiodący rej” w rozmowie, winien życzliwie odnosić się do młodych, zaprawiając swą mowę umiarkowaną dozą dowcipu. W tej kwestii wyraża następująco swoją opinię:

„Starsi powinni odnosić się do młodych jak do swych synów i mogą od czasu do czasu z nimi pożartować, rzucając pod ich adresem jakąś dowcipną uwagę, zwłaszcza taką, która by ich pouczała o odpowiednim zachowaniu się. Mogą na przykład, zwracając się do kogoś, kto siedzi nieśmiały i milczący, powiedzieć: «Że też ty, synu, nie dajesz nikomu dojść do słowa». Taki żart utwierdzi jeszcze młodzieńca w skromności, uwydatniając w delikatny sposób, przez wypominanie mu rzekomej wady, posiadaną przezeń zaletę. Jest to jedna $\mathrm{z}$ doskonałych form nauczania. Coś podobnego stosuje się nieraz, gdy człowieka znanego ze wstrzemięźliwości i nie pijącego nic prócz wody, nazywa się żartobliwie nałogowym pijakiem. Jeśli jednak w towarzystwie znajduje się już więcej tego rodzaju żartownisiów, należy samemu raczej milczeć, by niepotrzebną gadaniną nie przelewać pełnego już kielicha. Przesada bowiem w żartowaniu jest zawsze niebezpieczna" ${ }^{\prime 14}$.

4. Wygląd sędziwy - tytułem do czci i chwały. Wygląd sędziwy, którego główną oznaką są siwe włosy, jest według Klemensa Bożą ozdobą i Bożym darem, który należy ludziom ukazywać w stanie niezmienionym, czyli naturalnym. Mając to na uwadze, Klemens Aleksandryjski kieruje do ludzi starych znamienny apel:

„Przede wszystkim nie należy ukrywać starości, która jest wiarygodna. Ten dar Boga należy z dumą prezentować wobec młodych ludzi, by zyskać ich szacunek"15.

Szukając genezy powyższych imperatywów, warto zwrócić uwagę na obyczajowość środowiska aleksandryjskiego, która w czasach Klemensa daleko odbiegała od ideału chrześcijańskiego. $Z$ dużą dozą dezaprobaty Klemens mówi o rozpowszechnionych po miastach „fryzjerniach”, które przez szereg wymyślnych zabiegów kosmetycznych, zajmują się zmienianiem naturalnego wyglądu ludzi, w tym również przefarbowywaniem siwych włosów ludzi starszych. Charakteryzując powyższe praktyki, Klemens, nie ukrywając swego oburzenia, pisze:

„Bo czyż istotnie nie jest to dowodem pewnego rodzaju zdegenerowania, gdy mężczyźni się golą aż do gładkiej skóry? Albo gdy sobie włosy farbują, czy też posiwiałe smarują rozmaitymi maściami, by wyglądać na blondynów? Zaiste, są to wszystko zabiegi ludzi zniewieściałych, zwłaszcza, że i czeszą się oni zupełnie podobnie jak niewiasty. Wydaje im się, że jak wąż potrafi zmieniać

\footnotetext{
${ }^{14}$ Tamże II 57, 1-2, GCS 12, 191, ALP I 349.

${ }^{15}$ Tamże III 63, 3, GCS 12, 271, przekł. własny.
} 
skórę, tak oni potrafią przefarbowywaniem i odmładzaniem zmieniać swą starczą głowę. Nie uświadamiają sobie, że choć sfałszują własne owłosienie i tak nie zdołają uniknąc zmarszczek, a tym mniej oszukać czas i uniknąć śmierci. Czemuż to ma się człowiek wstydzić starości? Wszak im bardziej zbliża się do końca życia, tym jest czcigodniejszy, bo wiekiem przewyższa go chyba tylko sam Bóg, ów odwieczny Starzec, starszy od całego świata [...]. Czytamy w Piśmie Świętym: «Koroną starości bogactwo doświadczenia» (Syr 25, 6); tego właśnie doświadczenia oznaką bywa siwizna. A oni tymczasem ów siwy włos, główny tytuł do należnego im szacunku, bezczeszcza. Czy zaś możliwe, by człowiek, który sfałszował swą głowę, zachował niesfałszowaną duszę? Mówi Apostoł: «Lecz wy nie tak nauczyliście się od Chrystusa. Wyście Go słyszeli i w Nim zostaliście nauczeni według prawdy, która jest w Jezusie, abyście wraz z dawniejszym życiem zwlekli z siebie starego człowieka» - ale nie tego osiwiałego, lecz «niszczonego przez żądze zwodnicze» i «odnowili się» - ale nie za pomocą farb i kosmetyków, lecz «duchem umysłu waszego, przyoblekając się w nowego człowieka stworzonego na obraz Boży w sprawiedliwości i świętości prawdziwej» (Ef 4, 20n)"”.

Zpowyższej wypowiedzijasno wynika,żewedług KlemensaAleksandryjskiego, starość jest statusem wyjątkowo uprzywilejowanym. Starzec, w pewnym sensie, upodabnia się do Boga, owego „odwiecznego starca”. Starzec tylko Boga ma starszego od siebie. $Z$ tej racji starzec jest człowiekiem, który zasługuje na cześć i szacunek. Farbując swoje siwe włosy, starzec, w pewnym stopniu, degraduje się ze swej godności. Stąd obowiązkiem starców jest strzec oznak starości, do których w pierwszym rzędzie należy siwizna i zachowywać je $\mathrm{w}$ naturalnym, tj. niezmienionym stanie.

Na zakończenie należy dodać, że w niniejszym artykule, zgodnie z założeniem, zostały głównie omówione przywileje i obowiązki ludzi starszych, dotyczące płaszczyzny życia towarzyskiego i obyczajowego. Należy dodać, że problematyka związana z tematem niniejszego artykułu jest tak bogata, że mogłaby stanowić przedmiot osobnego, obszerniejszego studium. Szczegółowego omówienia wymaga pozycja ludzi starych, w kontekście życia małżeńskiego i rodzinnego. Człowiek w podeszłym wieku ma prawo do opieki ze strony małżonki i dzieci. Zdaniem Klemensa:

„małżeństwo jest też pomocą dla człowieka podeszłego wiekiem. Stawia obok niego małżonkę, która świadczy mu opiekę i wychowuje dzieci z niej zrodzone, aby one z kolei pielęgnowały starszych rodziców"17.

\footnotetext{
${ }^{16}$ Tamże III 16, 2 - 17, 1, GCS 12, 245-246, ALP I 351.

${ }^{17}$ Stromata II 141, 2-3, GCS 52, 191, thum. Niemirska-Pliszczyńska I 223.
} 
Według Klemensa wiek sędziwy, w którym namiętności cielesne nie bywają już tak gwałtowne, szczególnie usposabia do poszukiwania wiedzy i mądrości. Na poparcie tej opinii, powołuje się na autorytet Platona:

„Mianowicie chwaląc starość dodaje: «Zapamiętaj to sobie: im bardziej tracą dla mnie urok inne przyjemności, mianowicie przyjemności cielesne, tym silniej pożądam rozkoszy umysłowo interesującej rozmowy»" "18.

Z tej racji starcy, którzy całe swoje życie poświęcili zdobywaniu mądrości i prawdziwej wiedzy (gnozy) oraz przez doskonałą miłość doszli do statusu przyjaciół Chrystusa - gnostyków, są szczególnie zobowiązani do podjęcia funkcji nauczycielskich i wychowawczych w Kościele ${ }^{19}$.

Ludziom sędziwym zatem, zdaniem Klemensa, $\mathrm{z}$ racji nabytego doświadczenia, wiedzy i mądrości, przysługujenaczelne miejsce w społeczności chrześcijańskiej. Ten status wiąże się zarówno z różnymi przywilejami jak i obowiązkami. W sposób szczególny daje się to zaobserwować na płaszczyźnie życia towarzyskiego. Do przywilejów starców należy prawo swobodnego używania wina podczas uczt. $Z$ tym przywilejem wiąże się obowiązek zachowania stosownych granic w piciu, które gwarantują zachowanie niezmąconego umysłu oraz swobodne panowanie nad ruchami ciała. Starcom przysługuje też przywilej prowadzenia ożywionej konwersacji w czasie uczt. Ich „rozmowność” nie może jednak przekształcać się w „rozwlekłe ględzenie” ani „,bezsensowne gadulstwo”. Wygląd sędziwy starców jest darem Bożym i Bożą ozdobą. Obowiązkiem starców jest zachowywanie swego starczego wyglądu w stanie naturalnym, czyli niesfałszowanym przez zabiegi kosmetyczne. Starcy mają prawo do opieki ze strony swych domowników. Ludzie sędziwi, którzy legitymują się odpowiednią formacją intelektualnomoralna, są zobowiązani do nauczania i wychowywania młodego pokolenia.

\section{THE OBLIGATIONS AND PRIVILEGES OF THE AGED PEOPLE ACCORDING TO CLEMENT OF ALEXANDRIA}

(Summary)

In an old man, Clement of Alexandria sees the ideal of a perfect Christian, who thanks to intellectual and moral formation, reached the status of God's friend. For this reason, he is entitled to the care of his family, to be honored and respected by the young people, to drink a wine and conduct conversations during the feasts and to undertake the functions of the teacher and housemaster. The old man is required to maintain a senile appearance without cosmetic procedures and to hold tactful conversations and to drink a wine in moderation during the feasts.

${ }^{18}$ Tamże III 18, 4, GCS 52, 204, thum. Niemirska-Pliszczyńska I 239; Plato, Respublica I 328D (Klemens zmienia nieco tekst Platona).

${ }^{19}$ Por. Stromata VI 106, 2; VII 67, 2; VII 104, 1-2. 